\title{
Labor Absorption and Its Impact on Gross Regional Domestic Product
}

\author{
Made Ika Prastyadewi, Agus Suman, Devanto Shasta Pratomo \\ Faculty of Economics and Business, Universitas Brawijaya \\ Jl. MT. Haryono 165 Malang, Jawa Timur, Indonesia 65145 \\ Phone: +62-341-551611, E-mail address: dede_gsu02@yahoo.com
}

\begin{abstract}
The objective of this study is to examine the determinants of labor absorption in the trade, hotel and restaurant sector and its impact on Gross Regional Domestic Product/GRDP at Bali Province. This study is important due to the fact that the GRDP in this sector is the highest compared to other sector but the labor absorption is lower than the agriculture sector. This study used panel data comprising 9 regencies/cities at Bali Province in the period 2003-2009 including fixed effect model and simultaneous equation model of Two-Stage Least Square. The results showed that GRDP, working age population, and the minimum wage have positive effect on employment, while the educated unemployment has no significant effect on the employment in the trade, hotel and restaurant sector. In addition, increases in employment and workers productivity have positive and significant effects the GRDP in the trade, hotel and restaurant sector at Bali Province.
\end{abstract}

Keywords: labor absorption, regional economic, panel data, fixed effect model

JEL Classification Codes: J2, J3, R1

\section{Penyerapan Tenaga Kerja dan Dampaknya terhadap Produk Domestik Regional Bruto}

\begin{abstract}
Abstrak
Tujuan dari penelitian ini adalah untuk mengetahui faktor-faktor yang mempengaruhi penyerapan tenaga kerja di sektor perdagangan, hotel, dan restoran dan dampaknya terhadap Produk Domestik Regional Bruto/PDRB di Provinsi Bali. Penelitian ini dilakukan berdasarkan fenomena bahwa sektor ini memiliki PDRB yang tertinggi di Bali tetapi penyerapan tenaga kerjanya masih berada di bawah sektor pertanian. Penelitian ini menggunakan data panel atas 9 kabupaten/kota di Provinsi Bali selama periode 2003-2009 dengan metode fixed effect dan Two-Stage Least Square/2SLS. Hasil penelitian ini menunjukkan bahwa PDRB, penduduk usia kerja, dan upah minimum memiliki pengaruh yang positif terhadap penyerapan tenaga kerja tetapi pengangguran terdidik tidak memiliki pengaruh yang signifikan. Sebagai tambahan, adanya kenaikan penyerapan tenaga kerja dan produktivitas pekerja memiliki pengaruh yang positif dan signifikan terhadap PDRB sektor perdagangan, hotel, dan restoran di Bali.
\end{abstract}

Kata kunci: penyerapan tenaga kerja, ekonomi regional, data panel, model fixed effect Kode Klasifikasi JEL: J2, J3, R1 


\section{Pendahuluan}

Pembangunan daerah bertujuan untuk mencapai kesempatan kerja penuh, mempertahankan stabilitas harga, meningkatkan pertumbuhan ekonomi dan mencapai keseimbangan neraca pembayaran dalam ruang lingkup daerah (Suparmoko, 1997). Otonomi daerah di Indonesia yang diberlakukan berdasarkan UU No. 32 Tahun 2004 tentang Pemerintah Daerah telah terbukti memberikan ruang gerak yang lebih leluasa kepada setiap daerah untuk meningkatkan kinerja perekonomian dan pembangunannya. Hal ini salah satunya tercermin dari peningkatan pertumbuhan ekonomi yang dialami oleh sejumlah daerah di Indonesia. Tingkat pertumbuhan ekonomi yang meningkat di banyak daerah ini dapat menjadi acuan terutama terhadap ketersediaan lapangan pekerjaan dan peningkatan pendapatan yang pada akhirnya akan meningkatkan kesejahteraan masyarakat secara keseluruhan sesuai dengan tujuan pembangunan.

Produk Domestik Regional Bruto (PDRB) adalah sebuah indikator yang digunakan untuk mengukur kondisi perekonomian atau pertumbuhan ekonomi pada suatu daerah. Secara sektoral PDRB juga dapat berfungsi untuk melihat seberapa besar sumbangan suatu sektor terhadap perekonomian suatu daerah. Semakin besar nilai sumbangan suatu sektor ekonomi tertentu ke dalam PDRB di daerah tersebut, maka diprediksi juga bahwa sektor tersebut dapat berkembang dan mampu berperan secara signifikan sebagai penyumbang dalam peningkatan pertumbuhan ekonomi daerah. Pening- katan pertumbuhan ekonomi ini diharapkan juga akan berdampak pada penambahan lapangan pekerjaan yang mampu menyerap angkatan kerja yang tersedia di daerah.

Bali adalah sebuah provinsi yang dikenal dan berkembang sebagai daerah pariwisata. Hal ini didukung oleh keindahan panorama serta keanekaragaman seni dan budaya yang tidak dimiliki oleh provinsi yang lain. Sumbangan dari kegiatan pariwisata ini salah satunya tercermin dari nilai PDRB Provinsi Bali yang didominasi oleh kontribusi sektor perdagangan, hotel dan restoran sebagai penyumbang terbesar secara sektoral terhadap PDRB Provinsi Bali. Seperti yang terlihat dalam Tabel 1, sektor perdagangan, hotel, dan restoran memberikan kontribusi tertinggi terhadap PDRB Provinsi Bali dibandingkan dengan sektor yang lain. Kontribusi sektor ini juga cenderung selalu meningkat setiap tahunnya dengan rata-rata kontribusi sebesar 31,21 persen setiap tahunnya. Berbagai peristiwa yang mengguncang kegiatan pariwisata Bali seperti Bom Bali I di tahun 2002 dan Bom Bali II di tahun 2005 sepertinya tidak terlalu berdampak parah dalam perekonomian provinsi ini. Hal ini cukup terlihat jelas dari perkembangan kontribusi sektor perdangan, hotel dan restoran pada tahun-tahun tersebut yang relatif stabil.

Sektor perdagangan, hotel, dan restoran di Provinsi Bali ini tidak hanya berperan dalam peningkatan PDRB saja, tetapi juga memiliki ruang lingkup yang luas menyangkut kepentingan masyarakat secara keseluruhan. Sektor ini diyakini juga telah memberikan kontribusi yang sangat besar bagi perekonomian daerah,

Tabel 1. Kontribusi 9 Sektor Terhadap PDRB Provinsi Bali Tahun 2003 - 2009

\begin{tabular}{lrrrrrrrr}
\hline \multirow{2}{*}{ Sektor } & \multicolumn{1}{c}{ Tahun } \\
\cline { 2 - 9 } & $\mathbf{2 0 0 3}$ & $\mathbf{2 0 0 4}$ & $\mathbf{2 0 0 5}$ & $\mathbf{2 0 0 6}$ & $\mathbf{2 0 0 7}$ & $\mathbf{2 0 0 8}$ & $\mathbf{2 0 0 9}$ & Rata-rata \\
\hline Pertanian & 22,28 & 22,07 & 21,79 & 21,54 & 20,85 & 19,87 & 19,86 & $\mathbf{2 1 , 1 8}$ \\
Pertambangan dan Penggalian & 0,65 & 0,65 & 0,64 & 0,62 & 0,60 & 0,59 & 0,59 & $\mathbf{0 , 6 2}$ \\
Industri Pengolahan & 9,66 & 9,58 & 9,54 & 9,46 & 9,75 & 9,95 & 9,95 & $\mathbf{9 , 7 0}$ \\
Listrik, Gas, dan Air Bersih & 1,46 & 1,47 & 1,47 & 1,49 & 1,52 & 1,56 & 1,55 & $\mathbf{1 , 5 0}$ \\
Bangunan & 3,88 & 3,90 & 3,89 & 3,86 & 3,87 & 3,90 & 3,37 & $\mathbf{3 , 8 1}$ \\
Perdagangan, Hotel, dan & $\mathbf{3 0 , 6 2}$ & $\mathbf{3 0 , 6 3}$ & $\mathbf{3 0 , 8 4}$ & $\mathbf{3 0 , 7 9}$ & 31,27 & $\mathbf{3 1 , 9 8}$ & $\mathbf{3 2 , 3 3}$ & $\mathbf{3 1 , 2 1}$ \\
Restoran & 10,22 & 10,28 & 10,39 & 10,47 & 10,96 & 11,27 & 11,24 & $\mathbf{1 0 , 6 9}$ \\
Pengangkutan dan Komunikasi & 7,10 & 7,32 & 7,44 & 7,54 & 7,38 & 7,26 & 7,08 & $\mathbf{7 , 3 0}$ \\
Keuangan, Persewaan, dan Jasa & 14,11 & 14,10 & 14,00 & 14,22 & 13,80 & 13,63 & 13,67 & $\mathbf{1 3 , 9 3}$ \\
Perusahaan & & & & & & &
\end{tabular}


Tabel 2. Persentase Penyerapan Tenaga Kerja di Provinsi Bali Tahun 2003 - 2009

\begin{tabular}{lrrrrrrrr}
\hline \multirow{2}{*}{ Rincian } & \multicolumn{1}{c}{ Tahun } \\
\cline { 2 - 9 } & $\mathbf{2 0 0 3}$ & $\mathbf{2 0 0 4}$ & $\mathbf{2 0 0 5}$ & $\mathbf{2 0 0 6}$ & $\mathbf{2 0 0 7}$ & $\mathbf{2 0 0 8}$ & $\mathbf{2 0 0 9}$ & Rata-rata \\
\hline Pertanian & 38,00 & 37,07 & 33,58 & 35,45 & 36,03 & 35,78 & 34,24 & $\mathbf{3 5 , 7 3}$ \\
Pertambangan dan Penggalian & 0,68 & 1,02 & 0,76 & 0,12 & 0,43 & 0,60 & 0,40 & $\mathbf{0 , 5 7}$ \\
Industri Pengolahan & 13,59 & 10,36 & 16,58 & 13,40 & 14,59 & 12,97 & 14,28 & $\mathbf{1 3 , 6 8}$ \\
Listrik, Gas, dan Air Bersih & 0,21 & 0,44 & 0,10 & 0,47 & 0,20 & 0,38 & 0,33 & $\mathbf{0 , 3 1}$ \\
Bangunan & 6,49 & 5,69 & 7,42 & 6,82 & 6,49 & 6,90 & 6,92 & $\mathbf{6 , 6 8}$ \\
Perdagangan, Hotel, dan Restoran & $\mathbf{2 2 , 8 9}$ & $\mathbf{2 6 , 6 4}$ & $\mathbf{2 1 , 9 6}$ & $\mathbf{2 1 , 5 8}$ & $\mathbf{2 3 , 3 3}$ & $\mathbf{2 3 , 7 4}$ & $\mathbf{2 3 , 7 7}$ & $\mathbf{2 3 , 4 2}$ \\
Pengangkutan dan Komunikasi & 3,93 & 4,69 & 3,69 & 3,96 & 3,90 & 4,57 & 4,18 & $\mathbf{4 , 1 3}$ \\
Keuangan, Persewaan, dan Jasa & 2,10 & 1,15 & 1,92 & 3,71 & 2,67 & 2,24 & 2,25 & $\mathbf{2 , 2 9}$ \\
Perusahaan & 12,10 & 12,93 & 14,01 & 14,49 & 12,36 & 12,81 & 13,63 & $\mathbf{1 3 , 1 9}$ \\
Jasa - jasa & & & & & & &
\end{tabular}

Sumber : BPS Provinsi Bali, Tahun 2003 - 2009

karena merupakan suatu kegiatan yang memiliki keterkaitan yang panjang baik ke depan maupun ke belakang dengan sektor-sektor lainnya (forward and backward linkages) dan dapat menggerakkan berbagai kegiatan ekonomi dalam masyarakat. Selain itu, sektor ini juga dapat dijangkau oleh masyarakat dari berbagai golongan karena banyak yang bersifat padat karya dan seharusnya juga mampu menyerap tenaga kerja lebih tinggi dibandingkan dengan sektor lainnya.

Meskipun demikian, apabila dilihat dari penyerapan tenaga kerjanya, ternyata persentase penyerapan tenaga kerja tertinggi di Provinsi Bali periode tahun 2003-2009 berada pada sektor pertanian dan bukanlah pada sektor perdagangan, hotel, dan restoran. Seperti yang terlihat pada Tabel 2, sektor pertanian mampu menyerap tenaga kerja secara rata-rata sebesar 35,73 persen setiap tahunnya dibandingkan dengan sektor perdagangan, hotel, dan restoran yang hanya mampu menyerap tenaga kerja sebesar 23,42 persen rata-rata per tahunnya. Dengan kata lain, nilai penyerapan tenaga kerja pada sektor perdagangan hotel dan restoran belumlah sebanding dengan kemampuan sektor ini dalam memberikan kontribusi bagi PDRB Provinsi Bali. Diperkirakan bahwa penyerapan tenaga kerja di sektor perdagangan, hotel dan restoran di Provinsi Bali masih potensial untuk dapat ditingkatkan, apalagi dengan sifat sektor ini yang padat karya. Dengan melihat kondisi tersebut maka untuk itu perlu dilakukan penelitian untuk mengetahui faktor-faktor yang dapat mendorong penyerapan tenaga kerja sektor perdagangan, hotel, dan restoran di Provinsi Bali dan bagaimana dampak dari penyerapan tenaga kerja sektor perdagangan, hotel dan restoran ini terhadap peningkatan PDRB Provinsi Bali.

Dalam beberapa literatur dan penelitian terdahulu telah dijelaskan beberapa faktor yang dapat mendorong penyerapan tenaga kerja di suatu daerah. Campbell dkk (2003) misalnya menyebutkan bahwa penyerapan tenaga kerja dipengaruhi oleh permintaan akan barang dan jasa, produktivitas, jumlah tenaga kerja, dan dan harga sumber daya lainnya. Penelitian yang dilakukan oleh Sitanggang dan Nachrowi (2004) menggunakan populasi, net migration, output, dan upah sebagai variabel-variabel yang mempengaruhi penyerapan tenaga kerja. Sedangkan, penelitian yang dilakukan oleh Siregar dan Sukwika (2007) memasukkan variabel upah, investasi, pengangguran terdidik, pendapatan regional, dan pendapatan rumah tangga sebagai variabel yang mempengaruhi penyerapan tenaga kerja.

Seperti yang telah disinggung di atas, penelitian ini memiliki dua tujuan utama, yaitu (1) untuk mengetahui faktor-faktor yang mempengaruhi penyerapan tenaga kerja sektor perdagangan hotel dan restoran di Provinsi Bali dan (2) mengetahui dampak dari penyerapan tenaga kerja sektor tersebut terhadap PDRB sektor perdagangan, hotel, dan restoran di Provinsi Bali selama periode 2003-2009. Beberapa variabel ketenagakerjaan yang dianggap penting sebagai penentu penyerapan tenaga kerja di sektor ini digunakan dalam penelitian ini termasuk di dalamnya adalah penduduk usia kerja, jumlah pengangguran terdidik dan tingkat upah minimum kota/kabupaten. Sebagai tambahan, dimasukkan juga variabel nilai 
PDRB sektor perdagangan, hotel, dan restoran sebagai variabel yang bersifat endogen. Selanjutnya, penelitian ini juga melihat dampak dari penyerapan tenaga kerja terhadap PDRB sektor perdagangan, hotel, dan restoran di Provinsi Bali. Hal ini berangkat dari teori-teori pertumbuhan dalam berbagai literatur ekonomi pembangunan bahwa tenaga kerja adalah merupakan determinan yang penting dari pertumbuhan ekonomi yang tercermin dari nilai PDRB-nya.

\section{Metode Penelitian}

Penelitian ini menggunakan metode analisis data panel yang merupakan gabungan antara data time series dan data cross section dari 9 kabupaten/kota di Provinsi Bali pada periode tahun 2003-2009, yang tidak lain merupakan periode pasca terjadinya Bom Bali I yang berdampak pada perekonomian Bali dan juga periode pasca kebijakan otonomi daerah. Data sekunder ini diperoleh dalam bentuk laporan tahunan dari Badan Pusat Statistik (BPS) Provinsi Bali dan beberapa dinas serta instansi terkait seperti Dinas Tenaga Kerja, Transmigrasi dan Kependudukan Provinsi Bali

Tujuan pertama dari penelitian ini adalah untuk melihat faktor-faktor yang mempengaruhi penyerapan tenaga kerja sektor perdagangan, hotel, dan restoran di Provinsi Bali. Beberapa variabel ketenagakerjaan yang diduga mempengaruhi penyerapan tenaga kerja sektor ini adalah penduduk usia kerja (PUK), tingkat pengangguran terdidik (PTD), dan upah minimum kota/kabupaten (UMK), kemudian ditambah variabel PDRB yang menggambarkan kondisi perekonomian secara makro. Dalam hal ini di dalam variabel PDRB digunakan lag ( $t-1)$ untuk melihat pengaruh kelambanannya. Dalam persamaan yang pertama ini dapat digunakan model persamaan tunggal (single equation) sebagai berikut:

$\ln Y_{1}=b_{0}+b_{1} \ln X_{1}+b_{2} \ln X_{2}+b_{3} \ln X_{3}+b_{4} \ln X_{4}$

dimana $Y_{1}$ adalah jumlah tenaga kerja sektor perdagangan hotel dan restoran yang menggambarkan sebagai penyerapan tenaga kerja, $\mathrm{X}_{1}$ adalah $\operatorname{PDRB}(\mathrm{t}-1)$ sektor perdagangan hotel dan restoran (PDRB), $\mathrm{X}_{2}$ adalah jumlah penduduk usia kerja (PUK), $X_{3}$ adalah jumlah pengangguran terdidik (PTD), $\mathrm{X}_{4}$ adalah tingkat upah minimum kabupaten/ kota (UMK), $\mathrm{b}_{0}-\mathrm{b}_{4}$ adalah koefisien regresi, dan ln adalah log natural.

Untuk menentukan model data panel yang paling tepat digunakan (diantara model fixed effect atau random effect) dalam menganalisis faktor-faktor yang mempengaruhi penyerapan tenaga kerja sektor perdagangan, hotel dan restoran di Provinsi Bali periode tahun 20032009 dilakukan pengujian dengan Uji Hausman.

Tujuan kedua dari penelitian ini adalah untuk melihat dampak dari penyerapan tenaga kerja sektor perdagangan, hotel, dan restoran di Provinsi Bali terhadap PDRB sektor perdagangan, hotel, dan restoran di Provinsi Bali. Untuk menjawab tujuan penelitian ini digunakan persamaan simultan dengan model kuadrat terkecil dua tahap atau Two-Stage Least Square (2SLS). Dalam persamaannya, setiap variabel yang digunakan dapat dibedakan menjadi dua jenis variabel, yaitu variabel eksogen dan variabel endogen. Variabel endogen adalah variabel yang dipengaruhi oleh variabel lain dalam model. Adapun yang menjadi variabel endogen dalam penelitian ini adalah penyerapan tenaga kerja dan PDRB. Sedangkan variabel eksogen adalah variabel yang menjelaskan variabel endogen yang terdiri dari jumlah penduduk usia kerja, pengangguran terdidik dan upah minimum pada masing-masing kabupaten/kota di Provinsi Bali.

Untuk menjawab tujuan penelitian kedua ini digunakanlah model persamaan 2SLS sebagai berikut:

Langkah Pertama :

$\ln \mathrm{Y}_{1}=\mathrm{b}_{10}+\mathrm{b}_{11} \ln \mathrm{Y}_{2}+\mathrm{b}_{12} \ln \mathrm{X}_{1}+\mathrm{b}_{13} \ln \mathrm{X}_{2}+\mathrm{b}_{14} \ln \mathrm{X}_{3}$

Langkah Kedua :

$\ln \mathrm{Y}_{2}=\mathrm{b}_{20}+\mathrm{b}_{21} \hat{\mathrm{Y}}_{1}+\mathrm{b}_{22} \mathrm{X}_{4}+\mathrm{v}$

dimana $Y_{1}$ adalah jumlah tenaga kerja sektor perdagangan hotel dan restoran (yang menggambarkan penyerapan tenaga kerja), $Y_{2}$ adalah PDRB sektor perdagangan hotel dan restoran (PDRB), $X_{1}$ adalah jumlah penduduk usia kerja (PUK), $X_{2}$ adalah jumlah pengangguran terdidik (PTD), $X_{3}$ adalah upah minimum kabu- 
Tabel 3. Deskriptif Data Penelitian, 2003-2009

\begin{tabular}{lcccccc}
\hline Keterangan & $\begin{array}{c}\text { Penyerapan } \\
\text { Tenaga } \\
\text { Kerja }\end{array}$ & PDRB & $\begin{array}{c}\text { Penduduk } \\
\text { Usia Kerja }\end{array}$ & $\begin{array}{c}\text { Pengangguran } \\
\text { Terdidik }\end{array}$ & $\begin{array}{c}\text { Upah } \\
\text { Minimum }\end{array}$ & Produktivitas \\
\hline Mean & 48.547 & 765.874 & 282.834 & 4.550 & 421.495 & 14,17 \\
Median & 43.754 & 428.700 & 304.381 & 3.606 & 407.047 & 13,03 \\
Maximum & 135.353 & 2.507 .452 & 487.956 & 11.7061 & 818.362 & 36,90 \\
Minimum & 13.510 & 191.465 & 125.410 & 1.147 & 139.451 & 5,76 \\
\hline Sumber : Hasil Olahan (2012) & & & & & &
\end{tabular}

paten/ kota (UMK), $\mathrm{X}_{4}$ adalah produktivitas tenaga kerja, $\mathrm{b}_{0}-\mathrm{b}_{4}$ adalah koefisien regresi, dan ln adalah log natural.

Langkah pertama pada model Two Stage Least Square (2SLS) sebenarnya adalah hampir sama dengan persamaan pertama dengan single equation di mana jumlah tenaga kerja sektor perdagangan, hotel dan restoran sebagai variabel dependen dan jumlah penduduk usia kerja, upah minimum, jumlah pengangguran terdidik sebagai variabel independen. Hanya saja yang membedakan dengan persamaan pertama adalah variabel PDRB yang digunakan tidak dalam bentuk variabel kelambanan (lag) untuk menggambarkan hubungan penyerapan tenaga kerja dan PDRB yang langsung dan bersifat simultan.

Pada langkah kedua, akan dilihat bagaimana dampak atau pengaruh dari penyerapan tenaga kerja sektor perdagangan hotel dan restoran terhadap PDRB sektor perdagangan, hotel, dan restoran, dimana variabel penyerapan tenaga kerja yang digunakan sekarang adalah merupakan variabel hasil estimasi dari persamaan pada langkah pertama. Sebagai tambahan, variabel produktivitas tenaga kerja ditambahkan ke dalam persamaan sebagai variabel kontrol. Untuk menguji terhadap kevalidan dari model simultan yang digunakan, maka sebelumnya dilakukanlah uji endogeneitas dari persamaan simultan tersebut.

Definisi Operasional Variabel. Pengertian dan batasan-batasan variabel yang digunakan dalam penelitian ini adalah sebagai berikut.

Penyerapan tenaga kerja adalah jumlah tenaga kerja atau penduduk berumur 15 tahun ke atas yang bekerja di kabupaten/kota di Provinsi Bali dalam periode tahun 2003-2009 yang dinyatakan dalam satuan orang.

$P D R B$ adalah jumlah seluruh nilai tambah sektor perdagangan, hotel dan restoran berdasarkan harga konstan tahun 2000 periode tahun
2003-2009 di kabupaten/kota di Provinsi Bali yang dinyatakan dalam satuan jutaan rupiah.

Jumlah penduduk usia kerja adalah adalah jumlah penduduk berusia 15 tahun keatas baik angkatan kerja maupun bukan angkatan kerja di kabupaten/kota Provinsi Bali periode tahun 2003-2009 yang dinyatakan dengan satuan orang.

Upah Minimum adalah standar upah minimum yang ditetapkan oleh pemerintah di kabupaten/kota Provinsi Bali periode tahun 2003-2009 yang dinyatakan dalam satuan rupiah.

Pengangguran terdidik adalah jumlah penduduk usia kerja (lulusan SMA hingga perguruan tinggi) yang tidak sedang bekerja dan sedang mencari pekerjaan yang dinyatakan dengan satuan orang.

Produktivitas adalah rasio antara nilai PDRB sektor perdagangan hotel dan restoran terhadap jumlah penyerapan tenaga kerja sektor tersebut dengan satuan juta rupiah/orang.

Deskriptif Data Penelitian. Tabel 3 menggambarkan statistik deskriptif dari data yang digunakan dalam penelitian ini. Seperti yang terlihat dalam Tabel 3, rata-rata penyerapan tenaga kerja sektor perdagangan, hotel dan restoran kabupaten/kota di Provinsi Bali tahun 2003-2009 adalah sebesar 48.547 orang, dengan penyerapan tenaga kerja sektor perdagangan, hotel dan restoran yang tertinggi terdapat di Kota Denpasar yang merupakan ibukota Provinsi yaitu sebesar 135.353 orang dan yang terendah berada di Kabupaten Bangli yaitu hanya sebesar sekitar 13.000 orang. Di sisi lain, yang menarik adalah bahwa ternyata PDRB sektor perdagangan, hotel, dan restoran yang tertinggi adalah berada di Kabupaten Badung, tidak berada di Kota Denpasar yang memiliki serapan tenaga kerja sektor perdagangan, hotel, dan restoran yang terbesar di Provinsi Bali. Kabupaten Badung sendiri memi- 
liki nilai PDRB tertinggi dikarenakan kabupaten tersebut merupakan sentral dari industri pariwisata di Provinsi Bali. Sedangkan Kabupaten Klungkung adalah kabupaten dengan kontribusi PDRB sektor perdagangan, hotel, dan restoran yang terendah di Provinsi Bali dan merupakan kabupaten yang banyak bergantung pada sektor pertambangan.

\section{Hasil dan Pembahasan}

\section{Kondisi Ketenagakerjaan Provinsi Bali}

Berdasarkan hasil Survei Angkatan Kerja Nasional (Sakernas) pada bulan Agustus 2010, keadaan ketenagakerjaan di Provinsi Bali tergolong cukup baik. Hal ini terlihat dari meningkatnya jumlah penduduk yang bekerja serta relatif kecilnya tingkat pengangguran. Bertambahnya jumlah penduduk akibat kelahiran, kematian dan migrasi berpengaruh terhadap jumlah angkatan kerja, penduduk bekerja dan pengangguran di Provinsi Bali. Kondisi ketenagakerjaan Provinsi Bali ini secara detail dapat dilihat pada Tabel 3.

Tabel 3. Jumlah Penduduk 15 Tahun Keatas Menurut Kegiatan, Agustus 2009-2010 (dalam ribuan orang)

\begin{tabular}{|c|c|c|}
\hline Kegiatan Utama & $\begin{array}{l}\text { Agustus } \\
2009\end{array}$ & $\begin{array}{l}\text { Agustus } \\
2010\end{array}$ \\
\hline Penduduk 15 Tahun Keatas & $2.728,75$ & $2.902,57$ \\
\hline Angkatan Kerja & $2.123,59$ & $2.246,15$ \\
\hline - Bekerja & $2.057,12$ & $2.177,36$ \\
\hline - Pengangguran Terbuka & 66,47 & 68,79 \\
\hline Bukan Angkatan Kerja & 605,16 & 656,42 \\
\hline $\begin{array}{l}\text { Tingkat Partisipasi Angkatan } \\
\text { Kerja (\%) }\end{array}$ & 77,82 & 77,38 \\
\hline $\begin{array}{l}\text { Tingkat Pengangguran } \\
\text { Terbuka (\%) }\end{array}$ & 3,13 & 3,06 \\
\hline
\end{tabular}

Sumber : BPS Provinsi Bali, Tahun 2011

Penduduk usia kerja sebanyak 2.902,57 ribu orang di bulan Agustus 2010, sebagian di antaranya sebanyak 2.246,15 ribu orang tergolong sebagai angkatan kerja, dengan kata lain Tingkat Partisipasi Angkatan Kerja (TPAK) mencapai 77,38 persen. Sisanya sebanyak 656.424 orang tergolong sebagai bukan angkatan kerja, yaitu mereka yang hanya memiliki kegiatan bersekolah dan mengurus rumahtangga. Penduduk usia kerja di bulan Agustus 2010 ini mengalami peningkatan sebesar 6,4 persen jika dibandingkan dengan Bulan Agus- tus 2009 yang jumlah penduduk usia kerjanya hanya sebanyak $2.728,75$ ribu orang.

Angkatan kerja terbagi dalam kelompok penduduk yang bekerja dan penganggur. Pada bulan Agustus 2010 jumlah penduduk yang bekerja meningkat sebesar 5,8 persen menjadi 2.177,36 ribu orang atau sebesar 96,94 persen dari jumlah angkatan kerja jika dibandingkan dengan bulan Agustus 2009. Meskipun tenaga kerja yang terserap cukup banyak yang ditunjukkan oleh jumlah penduduk yang bekerja, sektor-sektor perekonomian di Bali belum mampu menyerap seluruh potensi tenagakerja yang ada. Hal ini yang kemudian berakibat pada timbulnya pengangguran. Pada semester kedua tahun 2010, jumlah pengangguran di Bali mencapai 68.791 orang. Meskipun meningkat dari sisi jumlah, tingkat pengangguran di Bali menurun dibanding kondisi tahun sebelumnya. Tingkat Pengangguran Terbuka (TPT) sedikit mengalami penurunan dari 3,13 persen pada Agustus 2009 menjadi 3,06 di tahun 2010.

Jika dilihat berdasarkan wilayah tempat tinggal, pengangguran lebih banyak terdapat di daerah perkotaan. Sebagian dari jumlah pengangguran yang ada yaitu sebanyak 51.463 orang atau 74,81 persen tinggal di wilayah perkotaan. Hal ini bisa dilihat dari tingkat pengangguran di Kota Denpasar yang memiliki tingkat pengangguran tertinggi. Pada bulan Agustus 2010 tingkat pengangguran di Kota Denpasar mencapai 6,57 persen. Sebagai pusat perekonomian di Bali, tentu saja Kota Denpasar memiliki daya tarik tersendiri bagi pencari kerja. Hal ini yang kemudian memacu para pencari kerja baik mereka yang berada di luar Pulau Bali maupun yang berada di luar Kota Denpasar untuk bermigrasi dan tinggal di Kota Denpasar untuk mencari kerja. Penganggur di Bali sebanyak 68.791 orang dan lebih dari 43,21 persen di antaranya tersebar di Kota Denpasar dengan jumlah sebesar 29.724 orang. Wilayah lain yang memiliki tingkat pengangguran yang tinggi antara lain adalah Kabupaten Klungkung, Kabupaten Buleleng, dan Kabupaten Karangasem dengan TPT masing-masing sebesar 3,59 persen, 3,26 persen, dan 2,82 persen. Kabupaten lainnya memiliki tingkat pengangguran yang relatif rendah (kurang dari tiga persen). Tingkat pengangguran terendah 
terdapat di Kabupaten Bangli dengan TPT sebesar 0,65 persen (BPS Provinsi Bali, 2011).

Faktor-faktor yang Mempengaruhi Penyerapan Tenaga Kerja Sektor Perdagangan, Hotel, dan Restoran

Sebelum dilakukan analisis tentang faktor-faktor yang mempengaruhi penyerapan tenaga kerja di Provinsi Bali, maka dilakukanlah pengujian Hausman untuk memilih apakah Model Fixed Effect atau Model Random Effect yang lebih baik digunakan dalam analisis regresi data panel ini. Hipotesis dalam Uji Hausman ini dapat dijelaskan sebagai berikut:

Ho : Model Random Effect lebih baik

H1 : Model Fixed Effect lebih baik

Keputusan dalam pemilihan antara Fixed Effect maupun Random Effect yang akan digunakan dalam penelitian adalah dengan cara membandingkan nilai chi-square ataupun nilai probabilitas dengan nilai tabel pada tingkat keyakinan sebesar 95 persen. Hasil pengolahan dengan Program Stata untuk Uji Hausman menunjukkan angka statistik sebesar 98,07 dengan probabilitas 0,00. Hal ini berarti, dengan tingkat keyakinan sebesar 95 persen, model Fixed Effect adalah paling tepat digunakan untuk menganalisis penyerapan tenaga kerja sektor perdagangn, hotel dan restoran di Provinsi Bali periode tahun 2003-2009 ini dibandingkan dengan Model Random Effect.

Hasil estimasi regresi faktor-faktor yang mempengaruhi penyerapan tenaga kerja di sektor perdagangan, hotel, dan restoran di Provinsi Bali dengan menggunakan model Fixed Effect adalah seperti yang ditampilkan dalam Tabel 4. Seperti yang terlihat dalam Tabel 4, $\mathrm{PDRB}_{\mathrm{t}-1}$ dan UMK adalah berpengaruh positif dan signifikan dengan tingkat keyakinan 95\%. Penduduk usia kerja (PUK) juga menunjukkan pengaruh yang positif tetapi signifikan hanya dengan tingkat keyakinan 90\%, sedangkan pengangguran terdidik (PTD) tidak signifikan pengaruhnya terhadap penyerapan tenaga kerja sektor perdagangan, hotel, dan restoran di Provinsi Bali.

Seperti yang telah disinggung di atas, variabel penduduk usia kerja (PUK) memiliki pengaruh yang positif meskipun hanya dengan tingkat keyakinan sebesar 90 persen. Secara spesifik, adanya kenaikan 1 persen dari penduduk usia kerja akan menaikkan penyerapan tenaga kerja di sektor perdagangan, hotel, dan restoran sebesar 0,14 persen, ceteris paribus. Variabel jumlah penduduk usia kerja digunakan sebagai salah satu variabel yang diduga mempengaruhi penyerapan tenaga kerja sektor perdagangan, hotel, dan restoran di Provinsi Bali dikarenakan jumlah penduduk usia kerja bukan hanya mampu mempengaruhi penyerapan tenaga kerja secara keseluruhan, melainkan juga dapat mempengaruhi penyerapan tenaga kerja secara sektoral maupun per wilayah kabupaten/kota. Menurut Todaro (2000), secara tradisional, pertumbuhan penduduk dan angkatan kerja dianggap sebagai salah satu faktor positif yang memacu pertumbuhan ekonomi. Jumlah tenaga kerja yang lebih besar akan memacu meningkatnya jumlah tenaga kerja yang produktif. Tenaga kerja yang meningkat, bila diimbangi dengan peningkatan jumlah lapangan kerja yang tersedia, maka akan menjadi modal dalam memperlancar proses pembangunan. Sebaliknya ketika peningkatan jumlah angkatan kerja tidak diimbangi dengan meningkatnya jumlah lapangan kerja akan menimbulkan masalah tersendiri karena menciptakan pengangguran. Hasil analisis yang positif dan signifikan dalam penelitian ini menjadi indikasi bahwa pertumbuhan jumlah penduduk usia kerja di Provinsi Bali mampu

Tabel 4. Rangkuman Hasil Regresi Penyerapan Tenaga Kerja di Provinsi Bali Metode Fixed Effect

\begin{tabular}{llllll}
\hline Variabel Terikat & Variabel Bebas & Koefisien Regresi & Standar Error & t-hitung & Signifikansi \\
\hline Ln Penyerapan & Konstanta & 5,854 & 1,046 & 5,60 & 0,000 \\
Tenaga & LPDRB $_{\mathrm{t}-1}\left(\mathrm{X}_{1}\right)$ & 0,118 & 0,059 & 2,00 & 0,051 \\
Kerja & LPUK $\left(\mathrm{X}_{2}\right)$ & 0,144 & 0,080 & 1,81 & 0,076 \\
$\left(\mathrm{Y}_{1}\right)$ & LPTD $\left(\mathrm{X}_{3}\right)$ & $-0,010$ & 0,033 & $-0,31$ & 0,755 \\
R-square & LUMK $\left(\mathrm{X}_{4}\right)$ & 0,117 & 0,019 & 6,23 & 0,000 \\
$\mathrm{~N}$ & $=0,7539$ & F-hitung & $=17,08$ & & \\
\hline
\end{tabular}

Sumber: Hasil Olahan (2012) 
diimbangi dengan meningkatnya jumlah lapangan pekerjaan yang tersedia sehingga meningkatnya jumlah penduduk usia kerja berhasil menyebabkan semakin meningkatnya tenaga kerja yang mampu terserap khususnya di sektor perdagangan, hotel, dan restoran.

Hasil penelitian ini sejalan dengan penelitian yang dilakukan oleh Sitanggang dan Nachrowi (2004) yang menyebutkan bahwa peningkatan serta penurunan jumlah populasi akan berpengaruh terhadap penyerapan tenaga kerja sektoral 30 provinsi di Indonesia. Secara spesifik dijelaskan bahwa peningkatan jumlah penduduk berpengaruh positif terhadap penyerapan tenaga kerja sektor pertambangan dan manufaktur di Kalimantan serta sektor perdagangan hotel dan restoran di Bali. Selain itu, pertambahan penduduk juga berpengaruh positif terhadap penyerapan tenaga kerja sektor pertanian di Sulawesi Utara. Penelitian ini juga mendukung hasil penelitian yang dilakukan Edyan (2005) yang menyebutkan bahwa terdapat hubungan yang positif antara angkatan kerja dan penyerapan tenaga kerja di DKI Jakarta. Meningkatnya jumlah angkatan kerja di DKI Jakarta ternyata mampu meningkatkan jumlah penyerapan tenaga kerja di provinsi tersebut.

Hasil penelitian ini juga sesuai dengan pendapat banyak ahli lain yang menyatakan bahwa pertambahan penduduk itu sebenarnya bukanlah suatu masalah, terutama apabila dikelola dengan baik, melainkan sebaliknya merupakan unsur penting yang akan memacu pembangunan ekonomi. Bertambahnya penduduk usia kerja merupakan indikasi bertambahnya jumlah tenaga kerja produktif yang tersedia. Semakin banyak tenaga kerja produktif yang tersedia berarti semakin banyak juga jumlah tenaga kerja yang mampu diserap dalam pasar tenaga kerja. Akan tetapi, peningkatan jumlah penduduk usia kerja ini juga perlu diimbangi dengan ketersediaan lapangan pekerjaan yang mampu menyerap peningkatan jumlah tenaga kerja tersebut.

Untuk variabel pengangguran terdidik (PTD), hasil uji statistik menunjukkan bahwa secara parsial pengangguran terdidik tidak berpengaruh terhadap penyerapan tenaga kerja sektor perdagangan hotel dan restoran di
Provinsi Bali pada periode tahun 2003-2009 dengan tingkat keyakinan sebesar 95 persen. Hasil penelitian ini berlainan dengan penelitian yang dilakukan oleh Siregar dan Sukwika (2007) yang menemukan bahwa penyerapan tenaga kerja terdidik di sektor pertanian Kabupaten Bogor secara signifikan dipengaruhi oleh investasi dan pengangguran terdidik. Sedangkan di sektor jasa, penyerapan tenaga kerja terdidik dipengaruhi oleh upah, investasi, PDRB dan pengangguran terdidik.

Tidak berpengaruhnya jumlah pengangguran terdidik ini terhadap penyerapan tenaga kerja sektor perdagangan, hotel, dan restoran di Provinsi Bali kemungkinan besar disebabkan karena sektor perdagangan, hotel dan restoran merupakan sektor perekonomian yang kompleks. Sektor ini tidak hanya membutuhkan tenaga kerja yang terdidik dan terlatih saja, melainkan juga menyerap tenaga kerja yang tidak terdidik (terutama di sektor perdagangan dalam usaha informal). Oleh sebab itu secara umum jumlah pengangguran terdidik tidak berpengaruh secara signifikan terhadap jumlah penyerapan tenaga kerja di sektor perdagangan, hotel dan restoran. Beberapa kemungkinan lain adalah cukup besarnya penyerapan tenaga kerja profesional asing yang berasal dari luar negeri untuk mengisi kesempatan kerja di bidang pariwisata di Provinsi Bali, dan juga banyak terserapnya tenaga kerja terdidik di luar sektor perdagangan, hotel, dan restoran seperti pada sektor jasa, sektor keuangan dan sektor industri pengolahan.

Sedangkan untuk variabel upah minimum (UMK), hasil uji statistik menunjukkan bahwa secara parsial upah minimum mempunyai pengaruh positif dan signifikan terhadap penyerapan tenaga kerja sektor perdagangan hotel dan restoran pada di Provinsi Bali periode tahun 2003-2009 dengan tingkat keyakinan sebesar 95 persen. Secara spesifik, adanya kenaikan upah minimum sebesar 1 persen akan meningkatkan penyerapan tenaga kerja di sektor perdagangan, hotel, dan restoran di Provinsi Bali sebesar 0,117 persen. Dengan kata lain, hal ini berarti bahwa peningkatan upah minimum akan meningkatkan jumlah tenaga kerja yang diserap oleh sektor perdagangan, hotel, dan restoran. 
Tabel 5. Hasil Uji Endogenitas

\begin{tabular}{lllll}
\hline Test of Endogeneity of : PTK & & & & \\
$\mathrm{H}_{0}:$ Regressor is exogenous & & & & \\
\hline Wu-Hausman F test & $: 3.59$ & $\mathrm{~F}(1,59)$ & P-value & $: 0,0000$ \\
Durbin-Wu-Hausman chi-sq test & $: 61,982$ & Chi-sq (1) & P-value & $: 0,0000$ \\
\hline Sumber : Hasil Olahan (2012) & & & &
\end{tabular}

Hasil penelitian ini berbeda dengan teori pasar tenaga kerja yang kompetitif yang mana menyatakan bahwa terdapat pengaruh negatif dari tingkat upah terhadap kesempatan kerja (Marhaeni dan Dewi, 2004). Hasil penelitian ini juga berbeda dengan hasil penelitian yang dilakukan oleh Siregar dan Sukwika (2007), Sitanggang dan Nachrowi (2004), Bodart dkk (2002), Edyan (2005), serta Dimas dan Nenik (2009) yang menyatakan terdapat pengaruh negatif antara tingkat upah terhadap penyerapan tenaga kerja. Namun, penelitian ini sejalan hasil penelitian yang dilakukan oleh Elnopembri (2007) yang menyatakan terdapat pengaruh positif dan signifikan dari tingkat upah terhadap kesempatan kerja. Penelitian ini juga mendukung penelitian yang dilakukan oleh Choi (2007) yang menyimpulkan bahwa terdapat elastisitas yang positif antara kenaikan upah dan tenaga kerja yang berarti bahwa kenaikan pada tingkat upah akan meningkatkan jumlah penyerapan tenaga kerja.

Pengaruh positif dan signifikan dari Upah Minimum Kabupaten/Kota terhadap penyerapan tenaga kerja yang diperoleh dalam penelitian ini dapat disebabkan karena peningkatan Upah Minimum Kabupaten/Kota telah meningkatkan daya beli pekerja terhadap barang dan jasa. Dengan kata lain, meningkatnya Upah Minimum Kabupaten/Kota menyebabkan permintaan akan barang dan jasa juga menjadi meningkat. Oleh karena permintaan akan tenaga kerja merupakan suatu permintaan turunan (derived demand) dari permintaan terhadap barang dan jasa, maka ketika permintaan terhadap barang dan jasa mengalami peningkatan akan menyebabkan permintaan terhadap tenaga kerja akan ikut mengalami peningkatan. Dengan menurunnya Upah Minimum Kabupaten/Kota menyebabkan permintaan terhadap barang dan jasa akan berkurang. Menurunnya permintaan barang dan jasa akan direspon dengan pengurangan jumlah tenaga kerja yang digunakan, sehingga pada akhirnya akan menurunkan jumlah penyerapan tenaga kerja yang ada.

Hubungan yang positif antara tingkat upah minimum dan penyerapan tenaga kerja ini juga dapat diterjemahkan sebagai sebuah indikasi bahwa sektor perdagangan hotel dan restoran di Provinsi Bali ternyata tidak bergerak di pasar tenaga kerja yang kompetitif. Salah satu teori yang menjelaskan hubungan positif antara upah minimum dan penyerapan tenaga kerja adalah model monopsony dinamis (Dynamic Monopsony Model) yang dikembangkan oleh Machin dan Manning (1994) dan Manning (2003). Adapun asumsi dari model monopsoni dinamis ini adalah, pertama, yaitu ada beberapa perusahaan di dalam pasar yang menunjukkan bahwa perusahaan dalam pasar tenaga kerja bukanlah perusahaan tunggal, meskipun tidak sebanyak dalam pasar kompetitif. Kedua, pekerja memiliki informasi sempurna tentang peluang pekerjaan yang lebih baik di tempat lain yang ditawarkan oleh pengusaha lain selama periode waktu tertentu. Ketiga, mudah untuk mendapatkan tambahan tenaga kerja selama perusahaan menawarkan upah lebih tinggi di atas tingkat ekuilibrium. Sebagai konsekuensinya, konsisten dengan model monopsoni standar, maka tingkat upah akan memiliki hubungan yang positif dengan penyerapan tenaga kerja.

Sebagai variabel terakhir dalam persamaan pertama dimasukkan pengaruh dari PDRB dalam bentuk variabel kelambanan (lag). Hasil uji statistik secara parsial menunjukkan bahwa PDRB (dengan lag) berpengaruh positif terhadap penyerapan tenaga kerja sektor perdagangan, hotel dan restoran di Provinsi Bali periode tahun 2003-2009 dengan tingkat keyakinan sebesar 95 persen. Secara spesifik, adanya kenaikan PDRB (pada tahun yang lampau) sebesar 1 persen akan menyebabkan meningkatnya penyerapan tenaga kerja di 
sektor perdagangan, hotel, dan restoran di Provinsi Bali sebesar 0,118 persen. Hal ini berarti bahwa peningkatan nilai PDRB sektor perdagangan hotel dan restoran akan diikuti dengan meningkatnya jumlah penyerapan tenaga kerja sektor tersebut di Provinsi Bali.

Hasil penelitian ini sejalan dengan penelitian yang dilakukan oleh Siregar dan Sukwika (2007) yang menyatakan bahwa penyerapan tenaga kerja sektor industri dipengaruhi oleh PDRB sektor industri di Kabupaten Bogor. Selain itu, hasil penelitian ini juga mendukung penelitian yang dilakukan oleh Dimas dan Nenik (2009) yang menyatakan bahwa PDRB berpengaruh signifikan terhadap penyerapan tenaga kerja di DKI Jakarta secara baik secara simultan maupun secara parsial, dengan nilai koefisien menunjukkan bahwa ketika terjadi peningkatan PDRB sebesar satu persen, akan meningkatan penyerapan tenaga kerja di DKI Jakarta sebesar 1,23 persen. Penelitian yang dilakukan oleh Walterskirchen (1999) juga menyebutkan bahwa masih ada korelasi positif dan kuat antara pertumbuhan ekonomi dengan perubahan ketenagakerjaan di Uni Eropa. Tetapi ketenagakerjaan akan naik hanya jika tingkat pertumbuhan ekonomi melampaui keuntungan produktivitas tenaga kerja.

\section{Dampak Penyerapan Tenaga Kerja terhadap PDRB Sektor Perdagangan, Hotel, dan Restoran}

Tujuan penelitian yang kedua adalah melihat dampak dari penyerapan tenaga kerja di sektor perdagangan, hotel, dan restoran terhadap PDRB sektor perdagangan, hotel, dan restoran di Provinsi Bali. Seperti yang telah disinggung di atas, tujuan penelitian ini akan dipecahkan dengan sebuah persamaan simultan karena terdapatnya kemungkinan masalah endogeneitas antara penyerapan tenaga kerja dan PDRB. Akibat adanya endogenitas ini, estimator yang digunakan akan menjadi bias dan tidak konsisten apabila digunakan pendekatan Ordinary
Least Square. Untuk mengetahui apakah model persamaan dalam tujuan penelitian kedua ini sudah tepat untuk dijawab dengan model persamaan simultan, terlebih dahulu perlu dilakukan uji endogenitas.

Hasil uji endogenitas dengan menggunakan Program Stata ditampilkan dalam Tabel 5.

Hipotesis untuk uji endogenitas tersebut adalah sebagai berikut, dimana:

$\mathrm{H}_{0}$ : Estimasi adalah eksogen

$\mathrm{H}_{1}$ : Estimasi adalah endogen

Hasil uji menggunakan Program Stata menunjukkan bahwa nilai F-test adalah 1,59 dan nilai $\mathrm{p}$-value $=0,000$. Oleh karena itu dapat disimpulkan bahwa estimasi untuk menjawab rumusan masalah kedua mengenai dampak penyerapan tenaga kerja terhadap PDRB sektor perdagangan, hotel dan restoran di Provinsi Bali periode tahun 2003-2009 adalah bersifat endogen, sehingga permasalahan tersebut harus dijawab dengan model persamaan simultan atau tepatnya digunakan model Two-Stage Least square.

Tabel 6 menunjukkan hasil regresi dari persamaan kedua dengan menggunakan model Two-Stage Least Square. Seperti yang terlihat pada Tabel 6, penyerapan tenaga kerja memiliki hubungan yang positif dan signifikan terhadap PDRB. Dalam hal ini, adanya peningkatan jumlah penyerapan tenaga kerja sektor perdagangan, hotel, dan restoran sebesar 1 persen akan berdampak pada peningkatan PDRB sektor perdagangan, hotel, dan restoran di Provinsi Bali sebesar 1,55 persen. Sedangkan produktivitas, sebagai variable kontrol, juga memiliki pengaruh yang positif tetapi tidak signifikan. Nilai $R^{2}$ sebesar 0,7933 menunjukkan bahwa variasi naik turunnya nilai PDRB sektor perdagangan hotel dan restoran di Provinsi Bali periode tahun 2003-2009 sebesar 79,33 persen dipengaruhi oleh naik turunnya jumlah penyerapan tenaga kerja dan produktivitas tenaga kerja. Hasil ini juga memperkuat hasil penelitian bahwa memang benar terdapat hubungan

Tabel 5. Hasil Uji Endogenitas

\begin{tabular}{lllll}
\hline Test of Endogeneity of : PTK & & & \\
$\mathrm{H}_{0}:$ Regressor is exogenous & $: 3.59$ & $\mathrm{~F}(1,59)$ & P-value & $: 0,0000$ \\
\hline Wu-Hausman F test & $: 61,982$ & Chi-sq (1) & P-value & $: 0,0000$ \\
\hline Durbin-Wu-Hausman chi-sq test &
\end{tabular}

Sumber : Hasil Olahan (2012) 
Tabel 6. Rangkuman Hasil Regresi Dampak Penyerapan Tenaga Kerja Terhadap PDRB di Provinsi Bali (Second Step)

\begin{tabular}{llllll}
\hline \multicolumn{1}{c}{$\begin{array}{c}\text { Variabel } \\
\text { Terikat }\end{array}$} & Variabel Bebas & Koefisien Regresi & Standar Error & t-hitung & Sig. \\
\hline LPDRB & Konstanta & $-3,624$ & 2,130 & $-1,70$ & 0,089 \\
$\left(Y_{2}\right)$ & LTK $\left(\mathrm{Y}_{1}\right)$ & 1,550 & 0,205 & 7,57 & 0,000 \\
R-square & LPRO $\left(\mathrm{X}_{5}\right)$ & 1,150 & 0,093 & 0,109 \\
& $=0,7933$ & F-hitung & $=1010$ & & \\
\hline
\end{tabular}

Sumber: Hasil Olahan (2012)

yang positif dan saling mempengaruhi antara jumlah penyerapan tenaga kerja dan PDRB sektor perdagangan hotel dan restoran di Provinsi Bali.

Hubungan yang positif antara penyerapan tenaga kerja dan PDRB di sini memperkuat teori yang menyatakan bahwa terdapat hubungan yang saling mempengaruhi antara jumlah penyerapan tenaga kerja dan nilai PDRB sektor perdagangan hotel dan restoran di Provinsi Bali. Hubungan tersebut menunjukkan arah yang positif, sehingga kenaikan pada jumlah penyerapan tenaga kerja akan meningkatkan PDRB dan kenaikan pada nilai PDRB akan mampu meningkatkan jumlah tenaga kerja yang terserap.

Hasil penelitian ini sesuai dengan apa yang terdapat dalam teori produksi yang mana disebutkan bahwa tingkat output dipengaruhi oleh jumlah tenaga kerja dan modal. Meningkatnya jumlah tenaga kerja berarti akan juga meningkatkan jumlah barang dan jasa yang dihasilkan dalam suatu proses produksi. Hal ini sejalan dengan apa yang dikatakan dalam Boediono (1999) yang menyebutkan bahwa tenaga kerja merupakan faktor positif dalam merangsang pertumbuhan ekonomi. Irawan dan Suparmoko (2002) juga menyebutkan bahwa faktor tenaga kerja berpengaruh positif terhadap output yang dalam hal ini adalah PDRB.

Sebagai variabel kontrol, hasil uji statistik menunjukkan bahwa secara parsial produktivitas tenaga kerja sektor perdagangan hotel dan restoran berpengaruh positif dan signifikan terhadap PDRB sektor tersebut tetapi hanya dengan tingkat keyakinan sebesar 90 persen. Hal ini berarti kita dapat katakan bahwa peningkatan nilai produktivitas tenaga kerja sektor perdagangan hotel dan restoran akan meningkatkan nilai PDRB tersebut. Sebaliknya, penurunan produktivitas tenaga kerja akan menurunkan nilai PDRB sektor perdagangan hotel dan restoran.

Peningkatan produktivitas kerja akan menyebabkan waktu yang dibutuhkan untuk menyelesaikan 1 unit output akan berkurang. Hal ini berarti produktivitas akan menciptakan efisiensi dalam suatu proses produksi. Semakin produktif tenaga kerja dalam menghasilkan barang dan jasa, khususnya dalam sektor perdagangan hotel dan restoran, maka akan semakin meningkatkan nilai dari barang dan jasa tersebut, yang dalam penelitian ini dicerminkan dari nilai PDRB sektor tersebut.

Hasil penelitian ini sesuai dengan penelitian yang dilakukan oleh Siregar dan Sukwika (2007) yang menyimpulkan bahwa produktivitas sektor jasa, pertanian dan industri berpengaruh positif terhadap PDRB sektor jasa, pertanian, dan industri di Kabupaten Bogor dengan tingkat keyakinan sebesar 95 persen. Hasil penelitian ini juga sejalan dengan penelitian yang dilakukan oleh Casares (2007) yang menyimpulkan bahwa ketika terjadi peningkatan produktivitas pada sektor manufaktur, maka akan terjadi kenaikan tingkat pertumbuhan agregat yang diukur dengan nilai GDP.

\section{Simpulan}

Penelitian ini secara umum bertujuan untuk mengetahui faktor-faktor yang mempengaruhi penyerapan tenaga kerja sektor perdagangan, hotel dan restoran di Provinsi Bali dan dampaknya terhadap PDRB sektor tersebut selama periode tahun 2003-2009. Penyerapan tenaga kerja sektor perdagangan, hotel dan restoran di Provinsi Bali meningkat ketika 
terjadi peningkatan pada nilai PDRB (pada periode sebelumnya), jumlah penduduk usia kerja dan upah minimum kabupaten/kota. Pengangguran terdidik tidak memiliki pengaruh yang signifikan terhadap penyerapan tenaga kerja sektor perdagangan hotel dan restoran di Provinsi Bali. Hal ini dimungkinkan karena sektor perdagangan, hotel dan restoran di Provinsi Bali ternyata tidak selalu menyerap tenaga kerja terdidik yang tersedia di pasar tenaga kerja. Sektor ini pada kenyataannya juga banyak memberikan kesempatan kerja yang cukup besar bagi pencari kerja yang tergolong kurang terdidik. Sehingga perubahan apapun yang terjadi pada jumlah pengangguran terdidik di Provinsi Bali tidak mampu merubah jumlah penyerapan tenaga kerja pada sektor perdagangan, hotel dan restoran.

Upaya tercapainya penyerapan tenaga kerja yang tinggi demi berkurangnya jumlah pengangguran perlu menempatkan sektor perdagangan hotel dan restoran sebagai prioritas yang utama, disamping juga memperhatikan sector-sektor lainnya yang juga mendukung berkembangnya sektor unggulan ini. Untuk itu perlu dilakukan peningkatan kerjasama oleh berbagai pihak mengenai masalah keamanan yang sangat perkaitan erat dengan kondisi perekonomian Provinsi Bali yang bergantung pada sektor pariwisata. Keterbukaan mengenai informasi kesempatan kerja sesungguhnya patut juga untuk dikembangkan sehingga lapangan pekerjaan yang memerlukan tingkat pendidikan dan keahlian tertentu mampu diisi oleh para pencari kerja terdidik.

Peningkatan pada jumlah penyerapan tenaga kerja dan produktivitas tenaga kerja berdampak terhadap peningkatan nilai PDRB sektor perdagangan, hotel dan restoran di Provinsi Bali. Semakin banyak tenaga kerja yang terlibat dalam produksi barang dan jasa sektor perdagangan, hotel dan restoran dan semakin produktif tenaga kerja tersebut, maka output yang dihasilkan juga akan ikut meningkat. Hasil tersebut juga mempertegas terdapatnya hubungan yang saling mempengaruhi (simultan) antara jumlah penyerapan tenaga kerja dan nilai PDRB sektor perdagangan, hotel dan restoran di Provinsi Bali.

Sebagai tambahan, variabel-variabel yang berhubungan dengan pariwisata seperti jumlah kunjungan wisatawan ataupun jumlah hotel dan restoran disarankan untuk dapat ditambahkan sebagai variabel yang berpengaruh terhadap penyerapan tenaga kerja sektor perdagangan, hotel dan restoran pada penelitian selanjutnya. Dalam penelitian ini tidak dimasukkan variabel-variabel tersebut disebabkan keterbatasan dalam penelitian.

\section{Daftar Pustaka}

Boediono. 1999. Teori Pertumbuhan Ekonomi. Yogyakarta: BPFE.

Bodart, Ph. Ledent dan F. Shadman-Mehta. 2009. An Employment Equation For Belgium. Econ-Ires Universit'E Catholique De Louvain. June 10, 2009.

Campbell, R. McConnell, Stanley L. Brue, dan David A. Macpherson. 2003. Contemporary Labour Economics. USA: McGraw-Hill.

Casares, Enrique. R. 2007. Productivity, Structural Change in Employment and Economic Growth. Estudios Economidos. Vol. 22, No.22. p.335-355.

Choi, C.K. 2007. The Employment Effect of Economic Growth: Identifying Determinant of Employment Elasticity. Chonbuk National University.

Dimas dan Nenik Woyanti. 2009. Penyerapan Tenaga Kerja di DKI Jakarta. Jurnal Bisnis dan Ekonomi, Maret 2009 Vol. 16 No. 1, hal. 32-41.

Edyan Rachman. 2005. Analisis Faktor-Faktor Yang Mempengaruhi Kesempatan Kerja di DKI Jakarta. Tesis. Medan: Universitas Sumatera Utara.

Elnopembri. 2007. Analisis Faktor-Faktor Yang Mempengaruhi Penyerapan Tenaga Kerja Industri Kecil Di Kabupaten Tanah Datar Provinsi Sumatera Barat Tahun 1990-2004. Tesis. Yogyakarta: Sekolah Pasca Sarjana Universitas Gadjah Mada.

Irawan dan Suparmoko. 2002. Ekonomika Pembangunan. Yogyakarta: BPFE. 
Machin, S. and Manning, A. 1994. “The Effects of Minimum Wages on Wage Dispersion and Employment: Evidence from The UK Wages Council". Industrial and Labor Relations Review, 47(2), 319-329.

Manning, A. 2003. Monopsony in Motion. Princeton: Princeton University Press.

Marhaeni, A.A.I.N dan Manuati Dewi. 2004. Ekonomi Sumber Daya Manusia. Denpasar: Fakultas Ekonomi Universitas Udayana.

Onder, Kubra and Ayse Durgun. 2007. Effect of Tourism Sector on the Employment in Turkey: An Econometric Application. First International Conference on Management and Economics, 28-29 March. Albania

Sitanggang, I. Rohana \& Nachrowi, D. Nachrowi. 2004. Pengaruh Struktur Ekonomi pada Penyerapan Tenaga Kerja Sektoral: Analisis Model Demomerik di 30 Propinsi pada 9 Sektor di Indonesia, Jurnal Ekonomi dan Pembangunan Indonesia, Vol V No.01, 2004 Juli, hal 103-133.

Siregar, Hermanto dan Sukwika, Tatan. 2007. Faktor-Faktor yang Mempengaruhi Kinerja Pasar Tenaga Kerja dan Implikasi Kebijakannya Terhadap Sektor Pertanian di Kabupaten Bogor. Socio-Economic of Agriculture and Agribusiness. Vol 7 No. 3. Universitas Udayana

Suparmoko, M. 1997. PengantarEkonomi Makro. Yogyakarta: BPFE.

Todaro, M. 2000. Pembangunan Ekonomi di Dunia Ketiga Jilid I. Edisi Ketujuh. Jakarta: Erlangga.

Walterkirchen, Ewald. 1999. The Relationship between Growth, Employment and Unemployment in the European Economists For An Alternative Economic Policy (TserNetwork). Austrian Instituteof Economic Research, Workshop in Barcelona 16-18 September 1999. 